\title{
Resistance to Six Races of Ascochyta rabiei in the World Germplasm Collection of Chickpea
}

\author{
K.B. Singh* and $M V$ Reddy
}

\begin{abstract}
Ascochyta blight (caused by Phoma rabiet (Pass.) Khune \& J.N. Kapoor; syn. Ascochyla rabiet (Pass.) Lab.) is the most important disease of (hickpea (Cicer arietinum L.) in many countries. Progress in breeding blight-resistant cultivars has been hampered by the absence of dependable sources of resistance. An effort was made (1) screen the world germplasm collection against races of $P$ rabiet with the objective of identifying resistant sources. A total of $19343 \mathrm{germ}$ plasm accessions of chickpea (12 749 desi and 6594 kabuli types) were evaluated for resistance to six races of $P$ rabiet at Tel Hadya, Syria, between 1979 and 1991 . (eermplasm accessions were sown in the field dunng the mnter season and inoculated by scattenng ascox hyta blightdiseased chickpea debris and spraying a spore suspension of a mixture of six races of $P$ rabiet prevalent in byria and Lebanon. In greenhouse evaluations, germplasm accessions were grown in pots and inoculated by spraying the spore suspension of a composite of the six races; inoculated plants were incubated in plastic moist chambers for I wk. Blight severity was scored on a scale of 1 to 9, where 1 to $4=$ resistant, $5=$ tolerant, and $6109=$ susceptible. Only three desi accessions (IC ( 4475, ICC 6328, and ICC 12004) and two kabuli accessions (ILC 200 and ILC 6482) were resistant in repeated field and greenhouse evaluations. Another six desi and three kabuli accessions were resistant in repeated field tests but tolerant in greenhouse evaluations. I hese accessions will be used as sources of resistance in the ascochyta blight-resistance breeding programs.
\end{abstract}

$\mathrm{A}$ scochYIA BI ICHI is the most important foliar disease of chickpea in many countries. The disease develops in epiphytotic proportions when the relative humidity is $>60 \%$ and temperalures between 10 and $20{ }^{\circ} \mathrm{C}$ (Reddy and Singh, 1990b). Despite efforts to control this

K B Singh, Int Ctr for Agric Res in the Dry Areds (ICARDA), $P$ O Box 5466, Aleppo, Syria, and M V Reddy, Int Crops Res Inst for the Semi-Arid Tropics (ICRISA I). Patancheru P O . An dhrd Pradesh 502 324. Indid Joint contribution of ICARDA and ICRISAT Journal Article no. 1290 of ICRISAT Received 19 Sept 1991 "Corresponding author

Published in Crop Sa 33 186-189 (1993) disedse since it was reported early in the 20th century (Butler, 1911), It still causes serious losses in Southwest Asta and the Mediterranean region (Nene and Reddy, 1987) In the past 60 yr, considerable efforts have heen made to control the disedse using host-plant resistance (Singh and Reddy, 1991), hut with only limited success All blight-resistant cultivars developed in the Indian subcontınent became susceptible, probably duc to the appearance of new races (Singh and Reddy, 1991) A few resistant lines reported from Iran (Kalser, 1972) and Bulgarıa (Solel and Kostrinskı, 1964, Ganeva and Matsov, 1977) were found susceptible in I( ARDA screening

In recent years, a few sources of resistance to blight have been reported from IC ARDA and successfully used In Its breeding program (Singh et al , 1981, 1984, Reddy and Singh, 1984, Singh and Reddy, 1991) In view of both the importance of ascochyta blight-resistant cultivars in stabilizing chickped production and the trequent breakdowns of resistant sources identified in the past, d large-scale evaluation of the world germplasm collection mantaned in gene banks at the IC RISA I Center in Indid and ICARDA in Syrid was undertaken in search of new and better sources of resistance for use in breeding. Fvaludtions in the past were (1) conducted in the field or greenhouse and (II) used blight-intecled chickped debris or one race of the pathogen as inoculum In this paper, we report the results of evaluation of $\approx 20(00)$ accessions, both desi (angular, small, dark-colored seeds) and kabuli (ram-hedd-shaped, large, heige-colored seeds) types for resistance to six races of $P$ rabeel at I el Hadya, Syrid.

\section{MATERIALS AND METHODS}

Seed of 6594 kabulı ILC accessions was from the Legume Program and Genetic Resources Unit of IC ARDA in Tel Hadyd, Syrid Seed of 12749 desi ICC accessions were oblained from the Genetic Resiurcer Unit, IC RISAT, Indid Evaluation for 

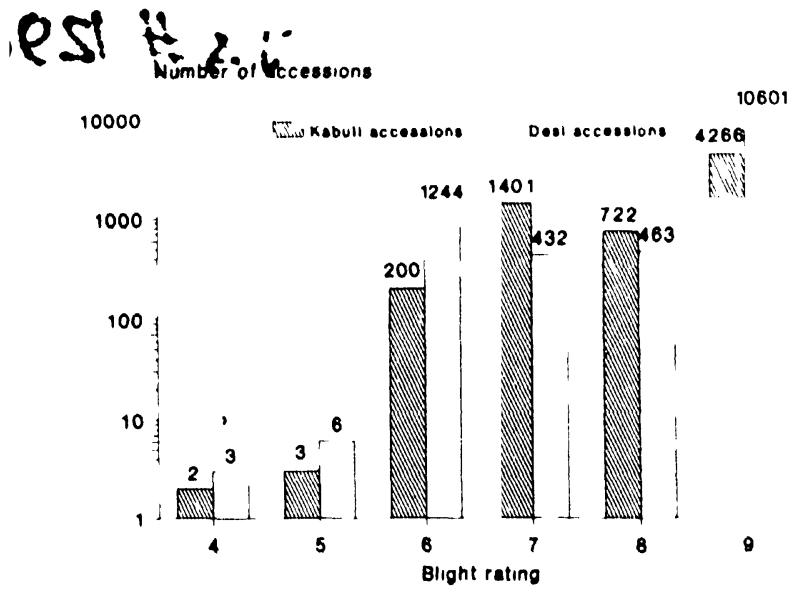

Fig. 1. Field and greenhouse evaluations of kabulh and desı chickpea germplasm accessions for resistance to ascochyta blight at ICARDA, Syna, 1979 to 1991.

blight resistance was conducted in the field between 1979 and 1991 The number of accessions evaluated each year ranged from 366 to 4306

Blight severity in the accessions was scored using a 9-class sale (Reddy and Singh, 1984, Reddy et al , 1984), where 1 $=$ immune reaction no visible lesions on stems and ledves, 2 = highly resistant no lesions on stems, but lesions on leaves, with few pycnidia, $3=$ resistant $5 \%$ stems, lcaves, and pods infected and stems broken, stem lesion $\leq 5 \mathrm{~mm}$ long, with few pycnidid, 4 - moderdtely resistant $15 \%$ steins, leaves, and pods infected and stems broken, stem lesion > $5 \mathrm{~mm}$ long, with few pycnidia, 5 - tolerant $40 \%$ stems, ledves, and pods infected and stems broken, stem lesion $>5 \mathrm{~mm}$ long, with more pycnidia, $6=$ moderately susceptıble $50 \%$ stems, leaves, and pods infected and stems broken, stem lesion $>5 \mathrm{~mm}$, with more pycnidid, $7=$ susceptible $75 \%$ stems, leaves, and pods infected and stems broken, stem lesion $>5 \mathrm{~mm}$ long, with more pycnidia, $8=$ highly susceptible $100 \%$ stems, leaves, and pods infected and stems broken, stem lesion $>5 \mathrm{~mm}$ long, with more pycnidia, and 9 = very highly susceptible all plants killed Scoring was done twice, the first score was taken when all plants in the susceptible check had died, and the second at harvest, mainly for pod infection

Except for 1991, accessions rated 1 to 5 in the first yedr of evaluation were reevaluated in subsequent years, along with new dccessions All of the 721 lines with a rating of 1 to 5 before 1990) were evaluated under greenhouse conditions dur ing 1990) These 721 lines were reevaluated in the field by inoculating with diseased debris and spore suspensions, which were prepared by mixing Six races in 1991

In field evaluations, generally 40 seeds were sown per acces sion in a single $4-m$ row in the first year Inter- and intrarow spacings were 45 and $10 \mathrm{~cm}$, respectively $A$ row of a known blight-susceptible line, ILC 263 or ILC 1929, susceptible to dll the six races was sown as an indicator row for the disease at an interval of 4 to 10 test rows In subsequent years, the selected accessions were sown in two replications in a random ized complete-block design and the susceptible controls were planted after every two test rows In addition, a strip of II C 1929 or ILC $263,3 \mathrm{~m}$ wide, was sown around the evaluation plot Germplasm accessions were sown between 10 November and 10 December This period is the beginning of the winter rainy scason, a more favorable period for blight development in the Mediterranean region than in the spring when chickpeas are normally sown

In February, plants were inoculated with $P$ rabie by scattering blight-diseased chickpea debris collected from the pre vious season (Singh et al , 1981) For the 1979 incculations, disedsed debris collected from naturally infested fields at the ICARDA farm was used In subsequent sedsons, the debris used was collected from the disedse nursery and stored in a field shelter Accessions were dlos inoculdted with a spore suspension of the prevaling races of the pathogen in Syria and Lebanon The fungus was multiplied on chickpea-dextrose broth (Reddy and Singh, 1984) During 1979, 1980, and 1981, dis eased debris and a spore suspension of a single race (the pre valing isolate of $\boldsymbol{P}$ rabiet at the ICARDA farm, later designated as Race 3) were used for inoculation (Reddy and Kabbabeh, 1985) Between 1982 and 1988, disedsed debris and a spore suspension of a mixture of Races $1,2,3$, and 4 was used During 1989, 19(0), and 1991, diseased debris and a spore suspension mixture of Races $1,2,3,4,5$, and 6 were used The races uere mixed in equal proportion to obtan d spore concentration of $1000(0 \times)$ spores $\mathrm{ml}$ ' of water, which was sprayed with knapsack sprayers Between inoculdtion and the time required for full disease development (d score of $y$ for the susceptible check ILC 263 or II $(1929)$, the nursery was sprinkler irrigated (1979-1988) or mist irrigated (1989-1991) for $3 \mathrm{~h} \mathrm{~d}$ ' during dry periods to increase relative humidity 10 $>60 \%$ Irrigation was repedted at the edrly podding stage of the crop for 1 wk to promote pord infection Spore suspension inoculations were contınued until the susceptible control line was killed Depending on the wedther, the number of spore suspension inoculations varied from three to seven (d gredter number of incculation sprays being required during a dry spring)

In the greenhouse, decessions were sown in sterilized soll in 20-cm plastic pots during 1990 in two replications In each pot, 10 seeds were sown per accession After every 10 pots of test accessions, a pot of the susceptible cultivar ILC 263 was grown Plants were inoculated when they were $15 \mathrm{~d}$ old with d spore suspension of the mixture of the six races and covered with dir tight plastic cages $(170 \mathrm{~cm}$ long, $135 \mathrm{~cm}$ wide, $60 \mathrm{~cm}$ high) for $7 \mathrm{~d}$ to increase the relative humidity to $>85 \%$ After removal of cages, plants were irrigated twice a day to raise the humidity Accessions were scored for blight severity $30 \mathrm{~d}$ dfter inoculation when the susceptible checks were kılled sur viving plants were reinoculated at the podding stage, covered with plastic cages for $7 \mathrm{~d}$, and scored for pord infection at harvest The greenhouse temperature was mantained at $20 \pm$ $2{ }^{\circ} \mathrm{C}$

\section{RESULTS AND DISCUSSION}

Of the 13 yr in which the germplasm was evaluated in the ficld (1979 to 1991), screening was dffected by waterlogging during 1985, an unknown race of $P$ rabiet durıng 1987, and severe cold during 1990. Results from these years were not considered. Evaluation for blight resistance was very effective in the remaining 10 years. The known blight susceptible lines ILC 263 and ILC 1929 were uniformly killed indicating high disease pressure. The distribution of accessions was skewed towards susceptibility. Only 1138 accessions were scored 5 or less in the first year of ficld evaluation. In reevaluations, many of these accessions had higher disease scores and were discarded.

Only nine desı $(0.07 \%)$ and five kabulı $(0.08 \%)$ accessıons were resistant or tolerant in repeated evaluations dgainst a composite of six races (Fig. 1). Only three desi (ICC-4475, ICC-6328, and ICC-12004) and two kabulı accessions (ILC-200 and ILC-6482) were resistant in both field and greenhouse evaluations (Table 1).

A large number of germplasm accessions that showed resistance in the early years of evaluation (1979-1988) were susceptible in later years (1989-1991). Also, most of the lines reported resistant earlier to a mixture of four 
Table 1 Mean and range of blight score of chickpea desi and kabulı accessions resistant or tolerant to a mixture of six races of Phoma rabies (the causal agent of ascochyta blight) from Syria, ICARDA, 1979 to 1991

\begin{tabular}{|c|c|c|c|}
\hline \multirow[b]{2}{*}{$\begin{array}{l}\text { Accession } \\
\text { no }\end{array}$} & \multicolumn{2}{|c|}{$\begin{array}{l}\text { Field evaluation, } \\
1979 \text { to } 1991\end{array}$} & \multirow{2}{*}{$\begin{array}{c}\text { Greenhouse } \\
\text { evaluation, } 1990 \\
\text { Mean blaght } \\
\text { scoret }\end{array}$} \\
\hline & $\begin{array}{l}\text { Mean blight } \\
\text { scoret (range) }\end{array}$ & $\begin{array}{c}\text { Years } \\
\text { no }\end{array}$ & \\
\hline \multicolumn{4}{|c|}{ Desı } \\
\hline $\begin{array}{l}\text { ICC } 3606 \\
\text { ICC } 4286 \\
\text { ICC } 4475 \\
\text { ICC } \mathbf{4 8 2 8} \\
\text { ICC } \mathbf{6 3 2 8} \\
\text { ICC } 8540 \\
\text { ICC } 8566 \\
\text { IC } 9584 \\
\text { ICC } 12004\end{array}$ & $\begin{array}{ll}3 & 0(2-4) \\
40 & (4-5) \\
35 & (3-4) \\
40 & (3-5) \\
35 & (3-4) \\
40(4-4) \\
40(4-4) \\
40(4-4) \\
30(3-3)\end{array}$ & $\begin{array}{l}2 \\
2 \\
4 \\
2 \\
2 \\
2 \\
2 \\
2 \\
3\end{array}$ & $\begin{array}{l}50 \\
50 \\
40 \\
50 \\
40 \\
50 \\
50 \\
50 \\
40\end{array}$ \\
\hline \multicolumn{4}{|c|}{ Kabulı } \\
\hline $\begin{array}{l}\text { ILC } 187 \\
\text { ILC } 200 \\
\text { ILC } 3856 \\
\text { ILC } 5913 \\
\text { ILC } 6482\end{array}$ & $\begin{array}{lll}3 & 0 & (2-4) \\
3 & 0 & (2-4) \\
3 & 0 & (3-4) \\
3 & 0 & (2-4) \\
4 & 0 & (4-4)\end{array}$ & $\begin{array}{l}9 \\
9 \\
6 \\
2 \\
2\end{array}$ & $\begin{array}{ll}5 & 0 \\
3 & 5 \\
50 \\
50 \\
20\end{array}$ \\
\hline
\end{tabular}

$+1-4=$ resistant, $5=$ tolerant, $6-9=$ susceptible

races (Reddy and Singh, 1984; Singh et al., 1984) were susceptible when later tested against a composite of six races. The nine desi and five kabulı germplasm accessions resistant or tolerant in both field and greenhouse evaluations to a mixture of six races should be very useful as sources of resistance in the ascochyta blight-resistance breedıng programs. Iranıan and Bulgarıan lines reported resistant earlier were susceptible in this screening. Some of the kabulı accessions such ds ILC 187 and ILC 200 also showed resistance in the field over nine scasons indicatıng stability of their resistance (Table 1 ). Two kabulı accessions, ILC 200 and ILC 3856, which were resistant in the present study were also reported resistant earlier (Singh et dl., 1984, Reddy and Singh, 1985), whereas other lines earlier reported as resistant were susceptible. This may be enturely due to screening against a composite mixture of six races.

The higher susceptibility of the lines in the greenhouse test than in the field could be due to more favorable conditions, especially temperature, for disedse development. In the field, relative humidity is favorable during most of the crop season (November to June), but because of low temperatures (mean weekly temperatures $<10{ }^{\circ} \mathrm{C}$ ) blight development in the early stages of crop growth up to March is retarded (Reddy and Singh, 1990b). From May onward, day temperatures are higher $\left(>25^{\circ} \mathrm{C}\right)$ and not favorable for blight infection. Relative humidity $>60 \%$ and temperatures between 10 and $20^{\circ} \mathrm{C}$ are favorable for blight development (Reddy and Singh, 1990b; Weltzien and Kaack, 1984). Therefore, field screenıng of germplasm accessions should be used as a prelımınary test to discard the bulk of susceptible lines.

Many lines that show resistance in the vegetative stage are susceptible in the podding stage (Reddy and Singh, 1984) and it is necessary to have lines resistant in both vegetative and podding stages, as the conditions for blight development are often favorable at podding tıme also. Earlier reports on resistance to blight were based mainly on evaluations at the vegetative stage (Reddy and Singh, 1984). Generally, des types have shown higher resistance in the vegetative stage than kabuli types, but higher susceptibility at the poodding stage. The lines identified in the present study have resistance at both the vegetative and podding stages and will be more useful in breeding programs

Some of the lines identified as resistant in the field in this study showed $<10 \%$ yield loss under severe disease pressure (Reddy and Singh, 199()a), while the suscept1ble lines had no yield. The fact that these lines do not have much yield loss with infection makes them useful in blight-resistance breeding programs

Phoma rabiet, the causal organism of the blight, is known to be a highly variable fungus (Nene and Reddy, 1987). Breakdown of resistance to the disedse is a frequent phenomenon (Singh and Reddy, 1991). Earlier sources of resistance to the disedse were identified mainly using a single isoldte of the fungus The lines that are identified in this study using disedsed debris and a mixture of six races may prove to be more durable. The diseased debris used for inoculation came from a screening nursery where several genotypes with different levels of susceptibility to blight have been grown; therefore, it comprises a mixed population of the blight pathogen $A$ s differential susceptible checks for different races were not used in the evaluation, the relative resistance of the accessions to individual races was not ascertained.

Five of the nine resistant or tolerant desi germplasm accessions identified in this study originated in Indid or Iran; the origin of four lines is unknown These nine accessions exhibit significant variation in maturity (52$91 \mathrm{~d}$ to $50 \%$ flowering) and plant height $(31-66 \mathrm{~cm})$ Mean canopy height of the resistant decessions was 48 $\mathrm{cm}$, as compared with a mean of $38 \mathrm{~cm}$ for all of the accessions evaluated. The resistant or tolerant accessions were mainly of erect or semierect type, with a large varlation in seed size (9.7-350 g l(0)-seed weight) The mean tume to $50 \%$ flowering of the resistant and tolerant accessions was $75 \mathrm{~d}$, ds compared with $36 \mathrm{~d}$ for all the accessions evaluated under blight-free conditions at ICRISAT Center, Indid (Pundir et al , 1988). These results suggest positive association between blight resistance, maturity, plant height, and erect growth habit in desı chickped resistant lines. Seed color also varied greatly from yellow to black. The observation made by Kaiser (1972) that blight resistance is associated with black seed color was not substantiated

Three of five kabulı resistant or islerant accessions originated from the USSR and one from Morocco. The origin of the other is not known. They were all late types with days to $50 \%$ flowering ranging from 142 to 145 . They were mainly tall $(50-78 \mathrm{~cm}$ height), with semierect growth habit. Their seed size was comparatively smaller (21.1-35.5 g 100-seed weight), and they are pea shaped. Mean tıme to $50 \%$ flowering, plant canopy height, and 100 -seed weight of the resistant and tolerant accessions recorded at ICARDA in Syrid were $143 \mathrm{~d}, 62 \mathrm{~cm}$, and $25 \mathrm{~g}$, ds compared with $137 \mathrm{~d}, 54 \mathrm{~cm}$, and $30 \mathrm{~g}$, respectively, for all accessions evaluated (Singh et al., 1991). While there seems to be some positive relationship between maturity, plant height, and blight resistance in kabulı germplasm, seed size is negatively associated; however, a large number of accessories with late matu- 
rity and tall plant stature were susceptible to ascochyta blight.

Screenıng of chickpea blight resıstance on such a large scale had not been done before. The work was undertaken because of frequent breakdowns of resistant sources owing to inadequacy of screening procedure. It is believed that resistant sources identified in this study will prove more useful in the ascochyta blight-resistance breeding programs.

Small quantities of seed of these five resistant lines are available from the Legume Program of ICARDA, Syria.

\section{REFERENCES}

Butler, E.J. 1911. Fungı and disease in plants. Reprint (1973). Dehradum Periodical Experts 42-D. Vivek Vihar, Delhi, Indid.

Ganeva, D., and B. Matsov. 1977. Comparative testıng of introduced and local samples of chickpea. Rast. Nauk. 1499:51-59.

Kaiser, W.J. 1972. Occurrence of three fungal diseases of chickpea in Iran. FAO Plant Prot. Bull. 20:74-78.

Nene, Y.L., and M.V. Reddy. 1987. Chickpea diseases and their control. p. 233-279 In M.C. Saxena and K.B. Singh (ed.) The chickped. CAB Int., Wallıngford, England.

Pundir, R.P.S., K.N. Reddy, and M.H. Mengesha. 1988. ICRISAT chickpea germplasm catalog: Evaluation and analysis. ICRISAT, Patancheru, A.P., India.

Reddy, M.V.. and S. Kabbabeh 1985. Pathogen variability in Ascochyta rabiet in Syrid and Lebanon. Phytopathol. Medit. 24:265-266.

Reddy, M.V., and K.B. Singh. 1984. Evaluation of a world collection of chickpea germplasm accessions for resistace to dscochyta blight. Plant Dis. 68:900-901.
Reddy, M.V , and K.B. Singh 1985. Explottdition of host-plant resistance in the management of ascochyld blight and other diseases of chickpea. p. 139-152. In M.C. Saxena and K.B. Singh (ed.) Ascochyta blight and winter sowing of chickpeas. Martınus Nıjhoff/Dr. W. Junk Publ.. The Hague, Netherlands.

Reddy, M.V., and K. B. Singh. $109 \times()_{3}$ Relationship beiween as cochyta blighi severity and yield loss in chickped dnd identifi. cation of resistant lines. Phytopathol. Medit. 20.32 38.

Reddy, M.V., and K.B. Singh. $19 x$ th. Reldilonship between temperature, relative humidity and ascochyta blight development in winter-sown chickpea in Syrid. Phytopathol. Medit. 20:159. 162.

Reddy, M.V., K.B. Singh, and Y.L. Nene. 1984 Screenıng techniques for Ascochyta blight of chickpeds. p. 45-54. In M.C. Saxena and K.B. Singh (ed.) Ascochyta blight and winter sowing of chickpeas, Mariınus Nihjoff/Dr. W. Junk Publ., The Hague, Netherlands.

Singh, K.B., G.C. Hawiın, Y.L Nene, and M V. Reddy. 1981. Resistance in chickpea to ascochyta blight. Plant Dis. 65:586 587.

Singh, K.B., L. Holly, and (i. Bejlgd. 1991. A catalog of kabuli chickpea germplasm: An evaluation report of winter-sown kabuli chickpea landraces, breeding lines and wild (ic er species. ICARDA. Aleppo, Syria.

Singh, K.H., and M.V. Reddy. 1991 . Advances in disedse resistance breeding in chickpea. Adv. Agron. 45.191-222.

Singh, K.B., M.V. Reddy, and Y.L. Nene. 1984. International testing of chickpeds for resistance to dscochytd blight. Plant Dis. 68:782-784

Solel, Z., and J. Kostrinskı. 1964. The control of ascochyı anthracnose of chickped. Phytopathol. Medit. 3:119-120

Welizien, $\mathrm{H}$, and H.J. Kadck. 1984. Epidemiological dspects of chickpea dscoschyta blighi. p. 35-44. In M.C. Saxend and K.B Singh (ed.) Ascochyta blight and winter sowing of chickpeds, Martınus Nıhhoff/Dr. Junk Publ., The Hague. Netherlands. 